\title{
A new species of Tripartiella (Ciliophora: Trichodinidae) from Aequidens tetramerus (Perciformes: Cichlidae) in north Brazil
}

\author{
M. L. Martins ${ }^{a *}$, N. Marchiori ${ }^{b}$, L. S. Bittencourt ${ }^{c}$ and M. Tavares-Dias ${ }^{c}$ \\ aLaboratório AQUOS-Sanidade de Organismos Aquáticos, Departamento de Aquicultura, Universidade Federal de Santa \\ Catarina - UFSC, Rodovia Admar Gonzaga, 1346, CEP 88040-900, Florianópolis, SC, Brazil \\ ${ }^{\text {b} E m p r e s a ~ d e ~ P e s q u i s a ~ A g r o p e c u a ́ r i a ~ e ~ E x t e n s a ̃ o ~ R u r a l ~ d e ~ S a n t a ~ C a t a r i n a ~-~ E P A G R I, ~ C a m p o ~ E x p e r i m e n t a l ~ d e ~ P i s c i c u l t u r a ~}$ \\ de Camboriú, Rua Joaquim Garcia, s/n, CEP 88340-000, Camboriú, SC, Brazil \\ 'Laboratório de Aquicultura e Pesca, Embrapa Amapá, Rodovia Juscelino Kubitschek, Km 5, 2600, CP 10 , \\ CEP 68903-419, Macapá, AP, Brazil \\ *e-mail: mauricio.martins@ufsc.br
}

Received: September 11, 2014 - Accepted: March 16, 2015 - Distributed: May 31, 2016

(With 2 figures)

\begin{abstract}
A new species of Tripartiella is described from the gills of the wild saddle cichlid Aequidens tetramerus in north Brazil. Wet smears of skin and gills of examined fish were air-dried at room temperature and impregnated with Klein's dry silver method for examination of the adhesive disc's structures and denticles. Total prevalence of parasitism was $65 \%$. This ciliate is characterized as a small-sized trichodinid, body diameter $37.03 \pm 4.9 \mu \mathrm{m}$, adhesive disc $30.50 \pm 2.71 \mu \mathrm{m}$, denticulate ring $13.28 \pm 0.8 \mu \mathrm{m}$ and $24 \pm 2.0$ denticles. Taxonomic and morphometric data for the new species are discussed.
\end{abstract}

Keywords: fish, protozoan, parasite, trichodinid, morphology.

\section{Uma nova espécie de Tripartiella (Ciliophora: Trichodinidae) em Aequidens tetramerus no norte do Brasil}

\section{Resumo}

Um nova espécie de Tripartiella encontrada nas brânquias de Aequidens tetramerus da região Norte do Brasil é descrita. Esfregaços de pele e brânquias de peixes examinados foram secos à temperatura ambiente e impregnados pelo método de Klein para observação das estruturas do disco adesivo e dentículos. A prevalência do parasitismo foi de $65 \%$. Este ciliado é caracterizado como pequeno trichodinídeo, com corpo medindo 37,03 \pm 4,9 $\mu$ m de diâmetro, disco adesivo com 30,50 $\pm 2,71 \mu \mathrm{m}$, anel denticulado com 13,28 $\pm 0,8 \mu \mathrm{m}$ e $24 \pm 2,0$ dentículos. Dados taxonômicos e morfométricos para a nova espécie são discutidos.

Palavras-chave: peixe, protozoário, parasito, tricodinídeo, morfologia.

\section{Introduction}

Trichodinids (Trichodinidae Claus, 1874) are a widely distributed group of ciliated ectoparasites of mollusks, fishes and amphibians (Mitra et al., 2013). Representatives of the genus Tripartiella Lom 1959, however, are only found on the gills of marine and freshwater fish (Tang et al., 2013). Up to now, there is only one Tripartiella species reported in Brazil, which is Tripartiella pseudoplatystomae Pinto, Garcia, Figueiredo, Rodrigues and Martins 2009, parasite of the pintado Pseudoplatystoma corruscans in the state of Mato Grosso do Sul, Central-Western Brazil. However, considering the wide variety of fish species in Brazil and the great abundance of fish trichodinids, it is reasonable to accept that much more species are yet to be reported.

The saddle cichlid Aequidens tetramerus (Heckel 1840) (Cichlidae) is endemic to South America and is commonly used as ornamental fish, sport fishing and also as food for the Amazon riverine populations (TavaresDias et al., 2014). In course of a parasitological survey of the protozoan parasites of this cichlid in north Brazil, a new Tripartiella species was found.

This study characterizes morphologically Tripartiella tetramerii n.sp. parasite of $A$. tetramerus from north Brazil. Taxonomic and morphometric data for the new species are discussed. 


\section{Material and Methods}

Sixty-three specimens of $A$. tetramerus were collected by net in November 2011 in the municipality of Macapá $\left(00^{\circ} 02^{\prime} \mathrm{N}, 51^{\circ} 03^{\prime} \mathrm{W}\right)$, Amapá State, Brazil.

Wet smears of fish skin and gills of collected fish were air-dried and impregnated with Klein's dry silver method for observation of the adhesive disc as suggested by Lom (1958). The span of the denticle was measured from the tip of blade to the tip of ray as described by Arthur and Lom (1984). The body diameter is the dimension of the adhesive disc plus the border membrane. Wet mounts from the specimens preserved in 5\% formalin solution were studied for the observation of adoral ciliature. All measurements are in micrometers and follow the recommendations of Lom (1958) and Van As and Basson (1989). Mean \pm standard deviation is followed, in parentheses, by the minimum and maximum values and number of specimens or structures measured.

\section{Results}

A total of $65 \%$ of examined fish were parasitized by the new Tripartiella species (mean intensity of infection: $2,379 \pm 1,344(1,233-3,567))$. Morphologically, it is characterized as a small-sized trichodinid, disc shaped. Blade of denticle elongated and straight, narrowing at distal end (Figure 1). Blade greater than ray. Tangent point rounded, lower than distal blade margin. Blade touching $\mathrm{Y}+1$ and $\mathrm{Y}$ axes. Anterior blade projection broad, prominent and wide, fitting into indentation of next denticle. Section connecting anterior projection and central part constricted. Central part of the denticle with a remarkable rounded spine directed backwards. Ray slender, lower than blade, straight, rounded in its distal extremity and directed towards the center of the adhesive disc. Central part extends $\mathrm{Y}+1, \mathrm{Y}$ and $\mathrm{Y}-1$ axes (Figure 2). Adoral ciliature spiral $381^{\circ}$. Morphometrical data is presented in Table 1 .

\section{Taxonomic summary}

Type Host: Aequidens tetramerus (Heckel, 1840)

Type locality: Macapá, Amapá State, north Brazil (00 02 ' 20” N, 51 03 ' 59” W)

Site of infection: gills

Etymology: The specific epithet "tetramerii" is derived from the name of the host species.

Reference material: Holotype and paratype slides are deposited in the National Institute of Amazonian Research (INPA 006, 007), Manaus, AM, Brazil.
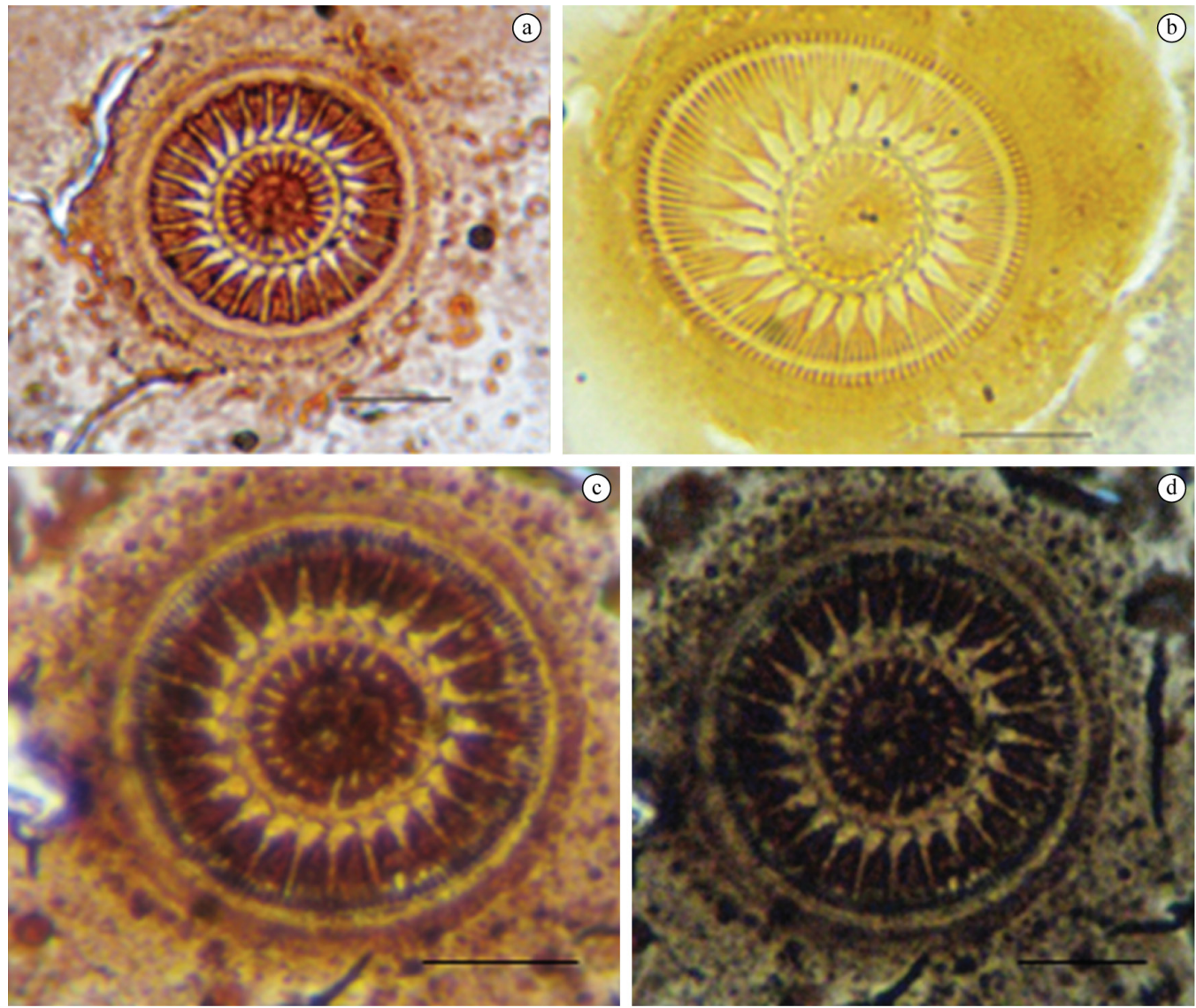

Figure 1. Photomicrographs ( $\mathrm{a}$ and $\mathrm{b}$ ) of silver impregnated adhesive discs of Tripartiella tetramerii $\mathrm{n}$. sp. from Aequidens tetramerus in north Brazil. Bar: $10 \mu \mathrm{m}$. 


\section{Remarks}

According to Gong et al. (2005), trichodinids are one of the most common parasitic ciliates that are well characterized by two main features: the morphology of the denticles in the adhesive disc and the development of the adoral ciliary spiral.

Denticles of both Tripartiella and Trichodinella species are wedged together both by central parts and anterior

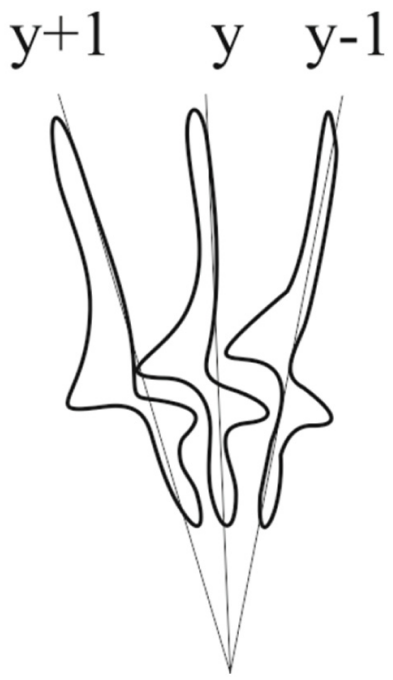

Figure 2. Schematic drawing of the denticles of Tripartiella tetramerii n.sp. from Aequidens tetramerus. blade projection (Lom and Haldar, 1977). However, whereas in the former genus it bears developed straight rays, the latter possesses short ray curved along the delicate central part.

Concerning to Tripartiella, the type species Tripartiella copiosa Lom, 1959 has been regularly reported on the gills of Cyprinidae and Cobitidae fish throughout the European and Asian continents (Lom and Haldar, 1977; Mitra et al., 2012; Mohilal and Hemananda, 2012). Morphologically, its ray resembles those of $T$. tetramerii n.sp. (both the species have thin rays, terminating in a rounded point); however, the shape of the blade of T. copiosa (broad, directed backwards) differs completely from the present studied specimens (narrow and straight), besides almost all biometrical data (Table 1).

Tripartiella pseudoplatystomae also shows similarities with $T$. tetramerii. Their blades are similar in shape, although in $T$. tetramerii it suffers a narrowing process through its apex (differently from the former, with the same width along the entire length). In addition, anterior blade projection of T. pseudoplatystomae is directed upwards, differently from the new species (Figure 1). Morphometric data between the two also differ in some characters (e.g. denticulate ring and number of denticles, see Table 1). Finally, the tip of ray in T. pseudoplatystomae is thin and pointed while in T. tetramerii it is slender and rounded. All other Tripartiella species differ from the new species in the shape of denticles and, therefore, are not discussed in the present study.

Table 1. Morphometric comparison of Tripartiella tetramerii n. sp. with Tripartiella pseudoplatystomae and Tripartiella copiosa.

\begin{tabular}{|c|c|c|c|}
\hline & $\begin{array}{l}\text { Tripartiella tetramerii n.sp. } \\
\text { Present study }\end{array}$ & $\begin{array}{c}\text { Tripartiella } \\
\text { pseudoplatystomae } \\
\text { Pinto, Garcia, Figueiredo, } \\
\text { Rodrigues and Martins } \\
\text { (2009) }\end{array}$ & $\begin{array}{c}\text { Tripartiella copiosa } \\
\text { Lom } 1959 \text { in Mohilal and } \\
\text { Hemananda (2012) }\end{array}$ \\
\hline Host & Aequidens tetramerus & $\begin{array}{l}\text { Pseudoplatystoma } \\
\text { corruscans }\end{array}$ & $\begin{array}{c}\text { Cirrhinus mrigala } \\
\text { Labeo rohita, Catla catla, } \\
\text { Cyprinus carpio }\end{array}$ \\
\hline Site of infection & Gills & Gills & Gills \\
\hline Body $^{\mathrm{D}}$ & $37 \pm 4.9(30.0-50.7 ; 17)$ & $36.2 \pm 3.7(28.0-42.0 ; 25)$ & $18.65(15.5-23.5)$ \\
\hline Adhesive disc ${ }^{\mathrm{D}}$ & $30.5 \pm 2.7(27.3-37.5 ; 17)$ & $31.9 \pm 3.6(23.0-36.9 ; 19)$ & $16.9(15.0-19.5)$ \\
\hline Denticulate ring $^{\mathrm{D}}$ & $13.2 \pm 0.8(11.8-14.8 ; 17)$ & $17.3 \pm 1.3(14.0-19.0 ; 19)$ & $7.85(6.5-9.0)$ \\
\hline Number of denticles & $24(23-25 ; 13)$ & $29.6 \pm 1.2(27.0-31.0 ; 24)$ & $22.6(20-25)$ \\
\hline Pins per denticle & $4.4 \pm 0.6(4-6 ; 13)$ & $5.9 \pm 1.2(5-7 ; 10)$ & $3.4(3-4)$ \\
\hline Denticle $^{\mathrm{L}}$ & $2.5 \pm 0.4(1.8-3.4 ; 20)$ & $3.5 \pm 0.6(3.0-4.0 ; 34)$ & $1.4(2.5-3.5)$ \\
\hline Blade $^{\mathrm{L}}$ & $7.1 \pm 0.4(6.3-8.0 ; 20)$ & $5.9 \pm 0.8(4.0-8.0 ; 35)$ & $4.0(3.5-4.5)$ \\
\hline Central part ${ }^{\mathrm{w}}$ & $1.2 \pm 0.1(0.9-1.6 ; 20)$ & $1.4 \pm 0.3(1.0-2.0 ; 34)$ & $0.7(0.5-1.0)$ \\
\hline $\mathrm{Ray}^{\mathrm{L}}$ & $2.0 \pm 0.2(1.5-2.4 ; 23)$ & $1.6 \pm 0.2(1-2 ; 34)$ & $1.75(1.0-2.5)$ \\
\hline Span & $10.6 \pm 0.7(9.2-11.8 ; 25)$ & $9.0 \pm 1.2(7.0-12.0 ; 35)$ & $5.3(4.5-6.0)$ \\
\hline
\end{tabular}

Mean \pm standard deviation is followed, in parentheses, by the minimum and maximum values and number of specimens or structures measured. Mean values are given in micrometers. ${ }^{\mathrm{D}}$ Diameter, ${ }^{\mathrm{L}}$ Length, and ${ }^{\mathrm{w}}$ Width. 


\section{Acknowledgements}

The authors thank CAPES for the Doctoral scholarship to Natalia Marchiori and the research productivity fellowship to Dr. M.L. Martins (CNPq 305869/2014-0) and M. Tavares-Dias (CNPq).

\section{References}

ARTHUR, J.R. and LOM, J., 1984. Trichodinid protozoa (Ciliophora: Peritrichida) from freshwater fishes of Rybinsk Reservoir, USSR. The Journal of Protozoology, vol. 31, no. 1, pp. 82-91. http://dx.doi.org/10.1111/j.1550-7408.1984.tb04294.x.

GONG, Y., YU, Y., FENG, W. and SHEN, Y., 2005. Phylogenetic relationships among Trichodinidae (Ciliophora: Peritrichia) derived from the characteristic values of denticles. Acta Protozoologica, vol. 44, pp. 237-243.

LOM, J. and HALDAR, D.P., 1977. Ciliates of the genera Trichodinella, Tripartiella and Paratrichodina (Peritrichia Mobilina) invading fish gills. Folia Parasitologica, vol. 24, pp. 193-210.

LOM, J., 1958. A contribution to the systematics and morphology of endoparasitic trichodinids from amphibians, with a proposal of uniform specific characteristics. The Journal of Protozoology, vol. 5, no. 4, pp. 251-263. http://dx.doi.org/10.1111/j.1550-7408.1958. tb02563.x.

MITRA, A.K., BANDYOPADHYAY, P.K., GONG, Y. and BHOWMIK, B., 2012. Occurrence of trichodinid ciliophorans (Ciliophora: Peritrichida) in the freshwater fishes of the river
Churni with description of Trichodina glossogobae sp. nov. in West Bengal, India. Journal of Parasitic Diseases, vol. 36, no. 1, pp. 34-43. http://dx.doi.org/10.1007/s12639-011-0073-0. PMid:23542238.

MITRA, A.K., BANDYOPADHYAY, P.K., GONG, Y., GOSWAMI, M. and BHOWMIK, B., 2013. Description of two new species of ectoparasitic Trichodina Ehrenberg, 1830 (Ciliophora: Trichodinidae) from freshwater fishes in the river of Ganges, India. Journal of Parasitic Diseases, vol. 37, no. 1, pp. 35-41. PMid:24431538.

MOHILAL, N. and HEMANANDA, T., 2012. Record of the species of Tripartiella (Lom, 1959) from fishes of Manipur. Journal of Parasitic Diseases, vol. 36, no. 1, pp. 87-93. http:// dx.doi.org/10.1007/s12639-011-0088-6. PMid:23542123.

TANG, F., ZHAO, Y. and LIU, C., 2013. First records of three Tripartiella species (Ciliophora, Oligohymenophora, Peritrichida) from freshwater fishes along Yangtze River in China. Zootaxa, vol. 3681, no. 2, pp. 169-174. http://dx.doi.org/10.11646/ zootaxa.3681.2.6. PMid:25232597.

TAVARES-DIAS, M., OLIVEIRA, M.S.B., GONÇALVES, R.A. and SILVA, L.M., 2014. Ecology and seasonal variation of parasites in wild Aequidens tetramerus, a Cichlidae from the Amazon. Acta Parasitologica, vol. 59, no. 1, pp. 158-164. http:// dx.doi.org/10.2478/s11686-014-0225-3. PMid:24570063.

VAN AS, J.G. and BASSON, L., 1989. A further contribution to the taxonomy of the Trichodinidae (Ciliophora: Peritrichia) and a review of the taxonomic status of some fish ectoparasitic trichodinids. Systematic Parasitology, vol. 14, no. 3, pp. 157-179. http://dx.doi.org/10.1007/BF02187051. 